\title{
Target Audience Differentiation through 3 Rivers, 1 Island Total Art Happening in Győr
}

\begin{abstract}
SUMMARY
Today's urban policies in Central and Eastern Europe place an increasing emphasis on cultur$\mathrm{al}$ and creative activities, as the industrial activity is not always sufficient for the development of cities - and thus the regions run by them - and needs to be supported by tourism, especially cultural tourism. Organising cultural events, art festivals and happenings has a major impact on the development of the urban milieu.

Today, events and festivals make a significant contribution to shaping the cultural image of a city. The key to the successful organization of festivals is the knowledge of the target audience, the differentiation, the most accurate segmentation of consumer groups. The present study showcases a detailed and comprehensive visitor analysis through 31! - 3 Rivers, 1 Island Total Art Happening organized by Győr in Hungary. The organizers aimed to rethink and consciously use the genre (happening instead of festival) to differentiate the event effectively, and to create a unique image, consciously building on the needs of a young target group, with a new emphasis on visuality.
\end{abstract}

Journal of Economic Literature (JEL) codes: $\mathrm{R} 1 ; \mathrm{Z} 1, \mathrm{Z} 32 ; \mathrm{Z} 33$
Keywords: Eastern and Central Europe, Győr; tourism; festival; happening, event, cultural and creative city; culture; total art.

The EFFEGTS OF GULTURAL FESTIVALS AND HAPPENINGS

In the field of cultural tourism, cities can gain major achievements in the field of event management (Kundi, 2012). For many destinations, festivals can act as a catalyst, helping to revitalize lesser-known areas by enhancing their image and developing tourism (Smith, 2009). The role of festivals in urban development has been the subject of intense and critical discourse both domestically and internationally since the 1990s, and despite their many and often voiced negative effects, their role in urban development continues to increase (Pachaly, 2008:16).

Cultural festivals, the so-called urban festivals, became widespread in Europe after World War II. Their characteristic was that they usually did not involve performers from a single field of art, but, from the outset, presented several forms of performing arts (initially mainly choir, music, and theatre). The choice of names of urban festivals in Western Europe was mainly determined by the place where the festival

Dr. KuPI Marcell, PhD student, Széchenyi István University, (kupi.marcell@ sze.hu), Tóthné Dr. Kardos Krisztina PhD, director, Győri Művészeti és Fesztiválközpont, (kardos.krisztina@mufegyor.hu). 
was held (e.g., Lucerne Festival (1938), Dutch Festival (1947), Berlin Festival (1951)), and the type was also included in the name next to the venue, e.g. opera festival (e.g., Verona Opera Festival, 1913) or music festival (e.g. Strasbourg Music Festival, 1932) (Szabó, 2011).

Eastern and Central Europe chose other means to identify festivals. It was not the name of the arts field or the city that determined the name of the festival and its function, but it deliberately focused on the target group, especially young people. Initially, the Association of Young Communists, later the World Federation of Democratic Youth organized the World Festival of Youth and Students. The first such meeting took place in Prague and then every 2-7 years it was always held in different countries. Of course, the hippie movement also appeared in this area in the $1960 \mathrm{~s}$, intending to contrast the young people's own culture with the prevailing lifestyle, customs and artistic trends. The organization of rock festivals began in the 1970s, and then folk music and amateur festivals came to the fore. Pop and rock festivals started in the 1980s, later the festivals gave way to the formation of ever larger subcultures in Eastern and Central Europe. With the easing of the dictatorship, cultural urban development ideas came to the fore, new types of festivals emerged (e.g., spring, summer, winter festivals). In the 1980s and 1990s, new types of festivals appeared in the Central and Eastern European region, based on popular music. Festivals were organized primarily to entertain the urban population because of the political message of the liveable city (Szabó, 2014).

Today, the demand for cultural tourism has increased to such an extent that we can also refer to it as an independent sector of tourism. This is also contributable to the fact that festivals are branded and have a complex supply profile, and the festival atmosphere also provides a unique experience that can be felt throughout the event area and promotes well-being. The atmosphere of festivals is the element that defines and distinguishes them from other musical events, and it also gives them outstanding attractiveness (Jászberényi et al., 2017). Today, the festival phenomenon has grown into a megatrend of cultural tourism. The number of festivals has grown exponentially over the past decade and a half (for example, 900 new small and large festivals were registered in Britain as early as 2007 (Long, 2008)).

The importance of festivals and happenings is unquestionable; today, it is a basic need of the young generation (experience society), a cool leisure programme, a competitive product that can be put on the market (Szabó, 2014). Most festivals held in cities are free of charge, which provides an opportunity to cultivate community relations, strengthen local patriotism, and in many cases, they bring significant tourism benefits (Tóthné, 2016; Jászberényi et al., 2016).

In Győr, home to 31!, an exemplary cooperation model has been established in the recent period, which called for a partnership of economic, cultural, scientific, regional, etc. actors interested in the city in the spirit of the concept of integrated urban development (Fekete, 2018). The 31 ! happening takes place in one of the most economically important cities in Hungary, where significant revenues are generated through the key role of the automotive industry, which the city also recycles for the development of its cultural life (Fekete-Rechnitzer, 2019).

The development of cultural tourism undoubtedly contributes to the social and economic well-being of the city. Nowadays, the spread of COVID-19 has drastically hampered the activities of the cultural sector. Evidently, culture is an important complement to the economic activities of urban regions, and we are now seeing good examples across Europe of being able to play a counterbalancing role to losses caused by traditional industrial and other economic activities.

Examining the new trends, events as a strategic tool are still much needed in the life of cities. Due to the coronavirus, the content of event as a term also changed by 2020, as it also received a new meaning due to the epidemic. Our study covers the findings of 31 ! - 3 Rivers, 
1 Island All Art Happening, drawing from events requiring personal offline participation, and it does not include the virtual and hybrid forms of the happening.

\section{The IMPORTANCE OF GROUPING EVENT VISITORS}

Cities are different in terms of size, geography, role, image, cultural and historical heritage. It should be borne in mind that each city also has different endowments in Europe, for example, historic cities offer a rich cultural heritage (e.g. Prague, Vienna, Brno, Kosice, etc.). Cultural, historical cities are already more attractive to visitors interested in culture. On the other hand, some cities can build less on their historical or cultural heritage in the field of tourism, so tourists visit them for completely different reasons, e.g. because of their natural attractions (Borg, 1994).

Urban events of increasing importance have emerged since the 1990s, and the new millennium has highlighted the importance of differentiation and diversification for organizers of urban events (Peters - Pikkemaat, 2005). Since urban tourism products are complex and consist of many elements, differentiation procedures can be diverse, requiring a clear division of interest groups in cities. There are three main interest groups in cities: residents, economic actors, and tourists.

Residents of different ages, as the largest local consumer group, not only look for everyday services and products but also become tourists of their settlement themselves when attending an event. At the same time, urban entrepreneurs also have a direct influence, for example through their social role. Finally, domestic and international tourists are a third important group of stakeholders, who are specifically looking for unique products and services as well as local culture and attractions, and therefore come to the given settlement (Peters - Pikkemaat, 2005). A combination of different factors is required for tourists to gain an urban tourism experience, with which the urban service pack- age is assessed qualitatively (Haywood - Muller, 1995).

More than $70 \%$ of Europe's population lives in cities. As a result, the majority of potential travellers who provide tourist demand are themselves urban dwellers, so they have a daily experience of how to utilize urban leisure spaces, how to "consume" the city, urban festivals. Urban spaces can be interpreted as a special cultural hub, where, in addition to the built heritage, cultural events are the most important attraction.

\section{EXAMPLES IN EASTERN AND CENTRAL EUROPE}

In recent decades, cities in Eastern and Central Europe have sought to catch up with the economic development of Western European countries mainly through the forced pace of industrial development and related programmes (Szirmai, 1996), while Western countries have invested in research and development, innovation, human capital and the cultural economy instead of fixed capital. In Western Europe, attempts have been made to offset the decline of the industrial pull sectors in a new way, through cultural and creative investments and the creation of research centers (Enyedi, 2005). Launched in 1985 as the European Capital of Culture (ECOC) initiative, the award-winning cities have been able to embark on cultural and creative renewal as a means for cities to embark on urban development processes, including the modernization of cultural infrastructure and the reinterpretation of the creative and cultural economy, but this included the organization of events and happenings (European Communities, 2009).

There are several cities in Central and Eastern Europe, some 120, with a population of between 70,000 and 500,000. This distinction is also important for cultural events, after all, the festival market is of an atomized nature, with a few international and national events with a particularly high number of visitors, as well as a small number of regional and local events that often attract fewer people due to their nature. 
The possibilities of grouping visitors, the importance of exploring the needs of tourists, and the importance of differentiation have been recognized by many event organizers in Eastern and Central European cities, who have been able to provide a more successful festival experience for their audiences, directly and indirectly in shaping cultural tourism.

For example, Ruda Slaska in Poland (population 139,412) organized the Festival of Colours in 2019 by appealing to a very wide age group, thanks to a targeted programme offer, and invited families and groups of friends to spray colorful powders on their guests while dancing at an outdoor music concert.

In Maribor, Slovenia (population: 94,370), the knowledge of the target audience also resulted in the successful Lent Festival, which offered a series of events of various genres, yet harmonized, with its gap-filling programme. Opera and ballet, theater and dance performances, jazz concerts, classical music, world music concerts, singer-songwriting concerts, ethno music concerts, folklore evenings, street theater performances, summer cinema, sports activities and children's programs appeal to a genre-sensitive audience.

Brno (population: 381,346 people) in Czechia hosted an event called PonavaFest despite the coronavirus. Although the event was held only for the 5th time in 2020, it has been already so intertwined with the city's cultural values that despite the pandemic, a significant portion of the community has been in demand for the festival. The festival attracts several generations from families with small children to older music-loving audiences.

Sziget Fesztivál (Island of Freedom) in Budapest (population: 1,752,286), almost adherent to foreign young people, cannot be left out of the list either,

It was first organized in 1993 primarily for young, more open-minded Hungarian audiences who are passionate about cultural and musical events, but today the festival has been targetting international, higher-spending foreign visitors, also through marketing activities.
In order to be successful, event organizers aim to reach the widest possible target group and the highest number of interested people through their programmes. Perhaps one of the most important things to do at the beginning of organizing events is to clarify who they are primarily for, who will visit them and for what purpose, that is, to clarify the purpose of the event and its message to its target audience. Whatever the event is, it is essential to identify the target group $(\mathrm{s})$, because if the target group whom we want to address is determined, the fundamentals of compiling an event theme are well defined and given.

When organizing events, the needs and trends of the primary target groups must always be considered, and this also applies to the structure of marketing communication. Integrated marketing communication, online and offline channels, and conscious coordination of tools is the primary goal in order to get the event's existence and message to the target audience as effectively as possible. It is fortunate to have the opportunity to conduct indicatorbased research during and after the event, because feedback will help the event organizers' work. The aim of the research is for the organizers to get to know the target audience, to be able to differentiate, to segment the consumer groups as accurately as possible to further increase the access to the main target group and their satisfaction at the next event.

\section{1! - 3 RIVERS, 1 ISLAND, TOTAL ART HAPPENING}

Before 2018, one of the major regional centres of Hungary, Győr (population: 129,435), had a large market gap due to the lack of an event with artistic synergies for the Generation $\mathrm{Y}$ and $\mathrm{Z}$ target audiences, thus, recognizing the needs of the audience, the city event organizing office, the Győr Art and Festival Centre, designed the 31! - 3 Rivers, 1 Island, Total Art Happening (hereinafter: 31 !).

The happening aims to tear young people out of cyberspace and strengthen social rela- 
tionships, making generations $\mathrm{Y}$ and $\mathrm{X}$ sensitive to culture and cultural consumption.

The riverbanks of Győr are the scene of social life of young people, so it was the perfect scene for 31 ! as well. With this, the organizers take the happening directly to the selected "consumer" group and make the cultural experience with unique visual elements that are not available on a smartphone.

The 31 ! is a very young event: it was held for the first time in 2018, so it took place only twice until the article was published. On both occasions, 7 branches of art were given the opportunity to introduce themselves: music, dance, photography, literature, architecture, fine arts and light art.

What made the event special was that the programme of each branch of art was working as an independent microfestival itself. The involvement of local artists or local professionals was a prerequisite when selecting the contributors.

The event is built around a specific theme every year; in 2018, in the year of the European
Capital of Culture 2023 competition, in connection with the competition, it was "FLOW / Győr, the city of rivers".

In 2023, a Hungarian city will become the European Capital of Culture, and in 2018, the international jury decided in favour of Veszprém against Debrecen and Győr in the second round of the selection process.

In 2019, the theme of the happening was "SECRET", which was chosen because shared secrets connect people most closely through their experiences, exactly as art leaders connect this theme to the 7 branches of art. The organizers are committed to the environment and sustainable development, so the theme planned for 2020 would have been "NATURE". As for the happening in 2020, due to organizational problems and in accordance with the decision of the Hungarian government, the 2020 event was cancelled following the guidelines related to the global health emergency.

Despite its young age (2 years), the event already boasts of two trademarks: the EFFE Label, a quality stamp for remarkable arts festivals

\section{Picture 1: The 31! happening}

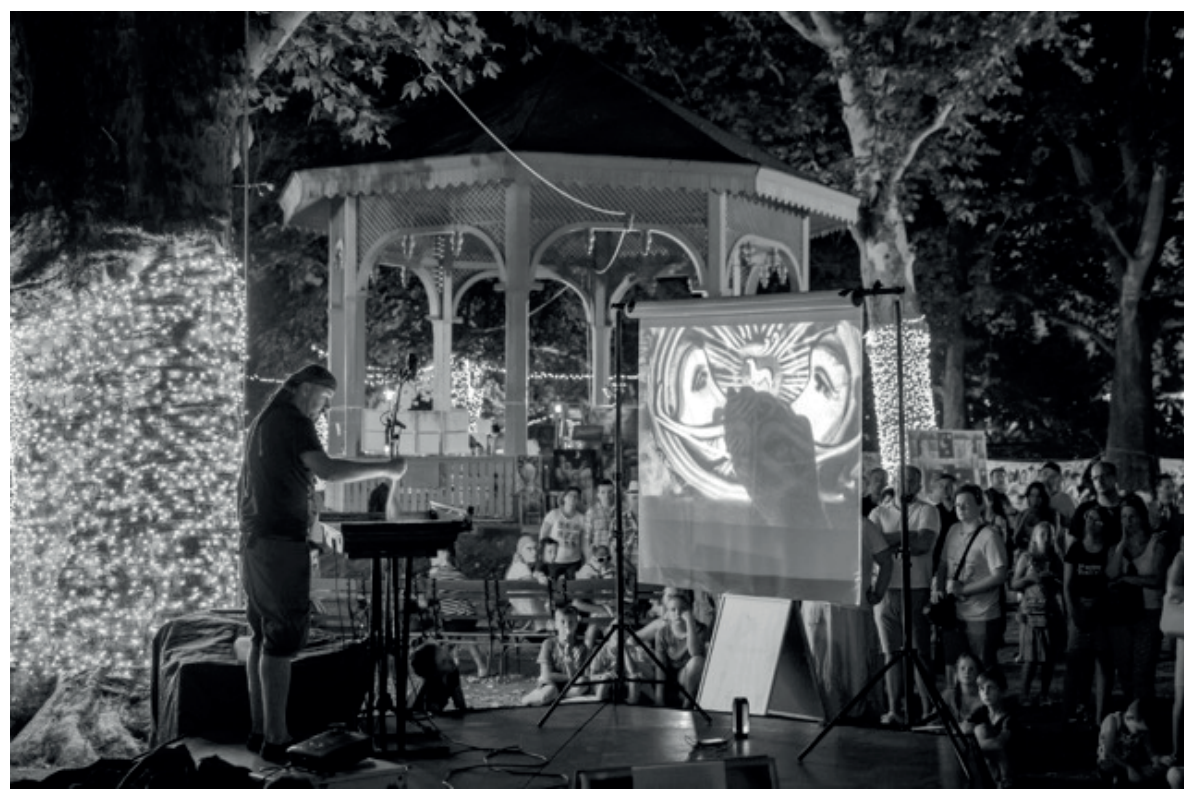

Source: http://31gyor.hu, downloaded: 29/09/2020 
awarded by the European Festival Association, and a double City Marketing Diamond Award.

The basic mission of the event is to make young people open and receptive to the cultural and creative "industry" and remain interested in culture and arts as adults. The long-term impact of the 31 ! event on culture and its role as catalyst in the social relations of the young generation was measurable for the first time.

The Győr Art and Festival Center has recognized the market niche and the importance of the above-mentioned differentiation since the early days of 31 st!. In our present study, the 31 ! presents a cluster analysis of its visitors based on two questionnaires.

\section{Presentation of the SAMPle}

For a better understanding of the audience and potential audiences, and to be able to differentiate more precisely, we examined the attitudes, motivations and preferences of the subjects during our research.

The questionnaire, as a data collection tool, ensured non-interference with personal space, anonymity, the processability of a large number of items and controllable probability sampling.

Our research was based on the distribution of two questionnaires. The questionnaire for the local, targeted sample was completed by 235 people during the event from 12 to 14 July 2019 in the presence of volunteer interviewers, on paper, coded in the week following the event.

The second questionnaire was filled in online, on the platforms of the organizing Györ Art and Festival Centre, on the social media channel of 31 !, and on the official website and Facebook site of the City of Győr. This opportunity was given for 5 days from the second day of the event. The statistical population in this case consisted of 210 people.

\section{Cluster Analysis - Online Questionnaire}

In order to get to know the habits of the con- sumer segments as much as possible, to map them, and thus devise the strategy of the 31 ! happening in a more conscious manner, we performed a cluster analysis.

Namely, if we know the habits of the consumer segment, it is possible to plan the introduction of a product in a targeted way, the demand for a new product can be estimated, and the audience can be further differentiated into smaller segments. Cluster analysis helps to accomplish such tasks. The task of the procedure is to identify individuals, products, or their characteristics, etc. and group them with the least possible overlapping between them (Lehota, 2001).

During the development of the questionnaire, we made scaling questions and attitude statements so that the main segments could be identified and outlined accurately. The main procedure for this was hierarchical cluster analysis, in which we grouped each respondent based on squared Euclidean distance, and we grouped each cluster member using Ward's method.

Based on the leading distances, we had the opportunity to create four separate clusters, so based on the data of the online questionnaire, we can distinguish the following cluster groups: a group of real lovers of art, a group of emerging lovers of art, a self-seeker group, and retractable people.

- Real lovers of art: They are interested in art festivals / happenings, go to festivals rather than theatre, prefer live art, like to build community life and relationships.

- Emerging lovers of art: Their interests are quite similar to the previous category, but their attitudes towards art are still developing. For each statement, the standard deviation of the responses is almost the double of that of the first cluster.

- Self-seekers: Although they are interested in art, they have a hard time choos- 
Table 1: 31! happening cluster statistics by the year of birth $(n=209)$

\begin{tabular}{l|l|c|c|c|c}
\hline \multicolumn{2}{l}{ Ward Method } & \multirow{2}{*}{ Mean } & \multirow{2}{*}{ Std. Deviation } & \multicolumn{2}{c}{ Valid N (listwise) } \\
\cline { 5 - 6 } & & & Unweighted & Weighted \\
\hline 1 & Year of birth & 1990,17 & 8,881 & 42 & 42,000 \\
\hline 2 & Year of birth & 1983,75 & 13,895 & 63 & 63,000 \\
\hline 3 & Year of birth & 1980,41 & 11,785 & 64 & 64,000 \\
\hline 4 & Year of birth & 1986,60 & 10,495 & 40 & 40,000 \\
\hline Total & Year of birth & 1984,56 & 12,185 & 209 & 209,000 \\
\hline
\end{tabular}

Source: IMB SPSS output table (created by own analysis)

ing between theater and festival, even cinema; they love book shows and community building programmes.

- Retractables: They are not really open to festivals, prefer to go to the cinema, do not like to be in a community, do not like book presentations, find them presumably boring, prefer pop music.

Table 1 shows the mean year of birth and summarizes standard deviations. As it can be seen, in the first cluster - the group of Real lovers of art - young people can be found; taking the ages ( years of birth) into account, the lowest standard deviation can be seen here. Based on the above data, Real lovers of art are surprisingly open to arts, which is also indicated in the description of their cluster characterization. Based on these aspects, we can call this the "strongest" cluster, it is worth continuing to target their group. The Self-seeker camp has the highest average age. In this camp, it is not worthwhile to focus on communication, because the people who belong here do not have a really developed attitude, they have a more attitude-forming effect on the 31 ! happening, so marketing and programming should also be addressed with this in mind.

The proportion of women in the total sample population is outstanding, which affects all clusters due to the composition of the sample, so gender could serve as a distorting factor in the analysis, but as Table 2 shows, the significance level is above 0.05 , i.e. belonging to a cluster is not significantly affected by gender.

Table 2: Gender and cluster membership Chi-Square test ( $n=209)$

\begin{tabular}{l|c|c|c}
\hline & Value & df & $\begin{array}{c}\text { Asymptotic Signifi- } \\
\text { cance (2-sided) }\end{array}$ \\
\hline Pearson Chi-Square & $1,860^{\mathrm{a}}$ & 3 &, 602 \\
\hline Likelihood Ratio & 2,018 & 3 &, 569 \\
\hline $\begin{array}{l}\text { Linear-by-Linear } \\
\text { Association }\end{array}$ & 1,248 & 1 &, 264 \\
\hline N of Valid Cases & 209 & & \\
\hline
\end{tabular}

${ }^{a} 0$ cells $(, 0 \%)$ have expected count less than 5 . The minimum expected count is 7,66.

Source: IMB SPSS output table (created by own analysis) 
Table 3: Cross-tabulation of clusters and education $(n=209)$

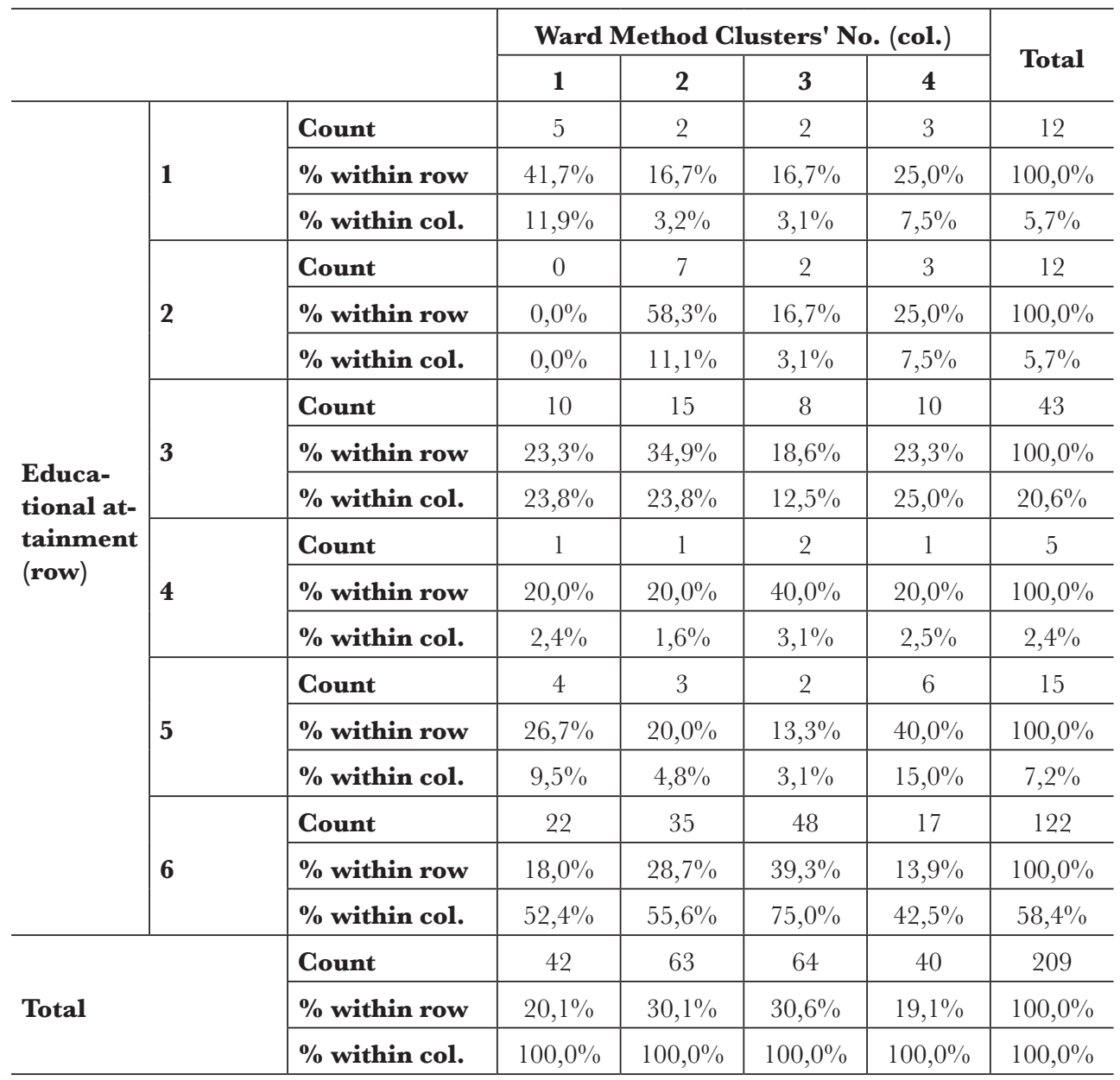

Source: IMB SPSS output table (created by own analysis)

A cross-examination of education and clusters (Table 3) shows that the proportion of real lovers of art (cluster group 1) is extremely high among those with primary education. However, this is not due to illiteracy, but rather to the younger average age found above, so presumably, most of them have not yet completed secondary education.

The proportion of graduates represents the highest proportion of all "festival-goers" visiting the happening, whose number is the highest in the 3 rd cluster.

As their attitude cannot be clearly inter- preted, they need to be offered the widest range of programs. Vocational school graduates / secondary school graduates and those with a secondary school leaving qualification are most likely to be found in cluster group 2, emerging lovers of art, and those currently pursuing higher education can be found in cluster 4, among retractable people.

These correlations are also confirmed by the Chi2 test, which confirms that belonging to the cluster is significantly influenced by educational attainment.

However, the test did not show a significant 
correlation in terms of the financial situation. Although we cannot talk about a correlation, it can be shown that $66.7 \%$ of real lovers of art can not make a living from their income, $25.9 \%$ of them do not have an independent income. The latter income category characterises $37 \%$ of emerging lovers of art, $36.7 \%$ of them live well and have savings, and 33\% can not make a living. In the Self-seeker camp, $46.2 \%$ can make a living from their income, $40 \%$ make a living from their income but cannot save, and $30 \%$ are well off and can put some money aside. The largest proportion of retractables did not want to answer the question $(26.8 \%)$, the other categories had roughly the same proportion (average: $18.5 \%$ ).

As far as the relationship is concerned, $33.8 \%$ of those living without children are emerging lovers of art, $22.5 \%$ are real lovers of art and retractables respectively, and $21.3 \%$ are self-seekers. Singles are mostly self-seekers $(32.8 \%)$ or emerging lovers of art $(31.3 \%)$, while a smaller proportion $(20.9 \%)$ are real lovers of art or $(14.9 \%)$ retractables. An outstanding percentage of people with children $(41.4 \%)$ came from the category of self-seekers, $20.7 \%$ $-20.7 \%$ from emerging lovers of art and retractables, and finally $17.2 \%$ from the real lovers of art group.

Table 4 shows the average responses of the four clusters about the programmes. In the first case, when surveying modern dance, we can see that those belonging to cluster 1 are most interested and the members of group 4 are the least. However, the majority of real lovers of art come from the younger age group, so this line-up is also logical. Interest in modern dance is most scattered in cluster $3(1,807)$, which may also be due to the fact that the members of this cluster do not yet have an acquired taste.

Table 4: Mean value and standard deviation of programmes in cluster breakdown (n=209)

\begin{tabular}{|c|c|c|c|c|c|c|c|}
\hline Program & Cluster & $\begin{array}{l}\text { Mean } \\
\text { value }\end{array}$ & $\begin{array}{c}\text { St. } \\
\text { dev. }\end{array}$ & Program & Cluster & $\begin{array}{l}\text { Mean } \\
\text { value }\end{array}$ & $\begin{array}{l}\text { St. } \\
\text { dev. }\end{array}$ \\
\hline \multirow{4}{*}{$\begin{array}{l}\text { Modern } \\
\text { dance }\end{array}$} & Real lover of art & 4,51 & 1,675 & \multirow{4}{*}{$\begin{array}{l}\text { Perfor- } \\
\text { mance } \\
\text { by young } \\
\text { poets / } \\
\text { poets / } \\
\text { slam-mers }\end{array}$} & Real lover of art & 4,63 & 1,496 \\
\hline & $\begin{array}{c}\text { Emerging lover } \\
\text { of art }\end{array}$ & 4,05 & 1,745 & & $\begin{array}{c}\text { Emerging lover } \\
\text { of art }\end{array}$ & 4,27 & 1,537 \\
\hline & Self-seeker & 4,19 & 1,807 & & Self-seeker & 4,70 & 1,560 \\
\hline & Retractable & 3,95 & 1,782 & & Retractable & 2,90 & 1,646 \\
\hline \multirow{4}{*}{$\begin{array}{l}\text { Art out- } \\
\text { doors } \\
\text { (E.g. open } \\
\text { painting } \\
\text { work-shop, } \\
\text { com- } \\
\text { munity } \\
\text { painting, } \\
\text { mosaic } \\
\text { painting) }\end{array}$} & Real lover of art & 4,59 & 1,612 & \multirow{4}{*}{$\begin{array}{l}\text { Book pre- } \\
\text { senta-tions }\end{array}$} & Real lover of art & 4,00 & 1,803 \\
\hline & $\begin{array}{c}\text { Emerging lover } \\
\text { of art }\end{array}$ & 4,73 & 1,358 & & $\begin{array}{l}\text { Emerging lover } \\
\text { of art }\end{array}$ & 4,63 & 1,195 \\
\hline & Self-seeker & 4,86 & 1,479 & & Self-seeker & 5,08 & 1,276 \\
\hline & Retractable & 3,15 & 1,688 & & Retractable & 2,78 & 1,544 \\
\hline \multirow{4}{*}{$\begin{array}{l}\text { Photo } \\
\text { exhibition }\end{array}$} & Real lover of art & 5,00 & 1,396 & \multirow{4}{*}{$\begin{array}{l}\text { Literary } \\
\text { pro- } \\
\text { duc-tions }\end{array}$} & Real lover of art & 4,12 & 1,706 \\
\hline & $\begin{array}{c}\text { Emerging lover } \\
\text { of art }\end{array}$ & 4,90 & 1,254 & & $\begin{array}{c}\text { Emerging lover } \\
\text { of art }\end{array}$ & 4,46 & 1,378 \\
\hline & Self-seeker & 5,06 & 1,344 & & Self-seeker & 4,84 & 1,371 \\
\hline & Retractable & 3,83 & 1,838 & & Retractable & 2,58 & 1,394 \\
\hline
\end{tabular}




\begin{tabular}{|c|c|c|c|c|c|c|c|}
\hline Program & Cluster & $\begin{array}{l}\text { Mean } \\
\text { value }\end{array}$ & $\begin{array}{l}\text { St. } \\
\text { dev. }\end{array}$ & Program & Cluster & $\begin{array}{l}\text { Mean } \\
\text { value }\end{array}$ & $\begin{array}{c}\text { St. } \\
\text { dev. }\end{array}$ \\
\hline \multirow{4}{*}{$\begin{array}{l}\text { Detective } \\
\text { games }\end{array}$} & Real lover of art & 4,24 & 1,700 & \multirow{4}{*}{$\begin{array}{l}\text { Sand } \\
\text { animation } \\
\text { / UV felt } \\
\text { paint-ing }\end{array}$} & Real lover of art & 4,78 & 1,458 \\
\hline & $\begin{array}{c}\text { Emerging lover } \\
\text { of art }\end{array}$ & 4,22 & 1,453 & & $\begin{array}{c}\text { Emerging lover } \\
\text { of art }\end{array}$ & 4,65 & 1,405 \\
\hline & Self-seeker & 3,91 & 1,659 & & Self-seeker & 4,72 & 1,506 \\
\hline & Retractable & 3,28 & 1,867 & & Retractable & 3,63 & 1,628 \\
\hline \multirow{4}{*}{$\begin{array}{l}\text { Board } \\
\text { games }\end{array}$} & Real lover of art & 4,05 & 1,788 & \multirow{4}{*}{$\begin{array}{l}\text { Light ins- } \\
\text { talla-tion }\end{array}$} & Real lover of art & 5,15 & 1,424 \\
\hline & $\begin{array}{l}\text { Emerging lover } \\
\text { of art }\end{array}$ & 4,37 & 1,324 & & $\begin{array}{c}\text { Emerging lover } \\
\text { of art }\end{array}$ & 5,29 &, 974 \\
\hline & Self-seeker & 4,06 & 1,680 & & Self-seeker & 5,42 & 1,096 \\
\hline & Retractable & 3,13 & 1,786 & & Retractable & 4,28 & 1,739 \\
\hline \multirow{4}{*}{$\begin{array}{l}\text { Music } \\
\text { concerts }\end{array}$} & Real lover of art & 5,68 &, 879 & \multirow{4}{*}{$\begin{array}{l}\text { Light } \\
\text { painting } \\
\text { / Light } \\
\text { animation }\end{array}$} & Real lover of art & 5,29 & 1,188 \\
\hline & $\begin{array}{c}\text { Emerging lover } \\
\text { of art }\end{array}$ & 5,56 & ,736 & & $\begin{array}{c}\text { Emerging lover } \\
\text { of art }\end{array}$ & 5,29 & 1,069 \\
\hline & Self-seeker & 5,47 & 1,007 & & Self-seeker & 5,42 & 1,152 \\
\hline & Retractable & 4,93 & 1,474 & & Retractable & 4,40 & 1,823 \\
\hline
\end{tabular}

Source: IMB SPSS output table (created by own analysis)

In the analysis of variance, the above statement showed a significant correlation between belonging to a cluster and interest in the programme in all cases, with the exception of modern dance.

\section{Cluster Analysis - Local Questionnaire}

Like the questionnaire shared online, the local questionnaire also identifies four different cluster groups:

- "Light" art lovers: They have a wellestablished, definite taste, they like live art, popular music, community programmes and music festivals, but at the same time they don't particularly like book shows and don't prefer theatre.

- Super art lovers: They are much more likely to choose theatre over both music festivals and cinema. Compared to the previous cluster, they have a much higher interest in live art, community programmes, they especially love book presentations, their hearts also draw in the direction of classical music.

Open-minded: Their personalities are extremely open. They have an interest in everything, be it a book presentation, art or light entertainment, but they like popular music and music festivals.

Style finder: Their interest is more difficult to describe, they are not characterized by clear openness. They do not have an established system of preferences or a definite opinion about artistic directions. 
Table 5: Cluster analysis summary table based on online questionnaires

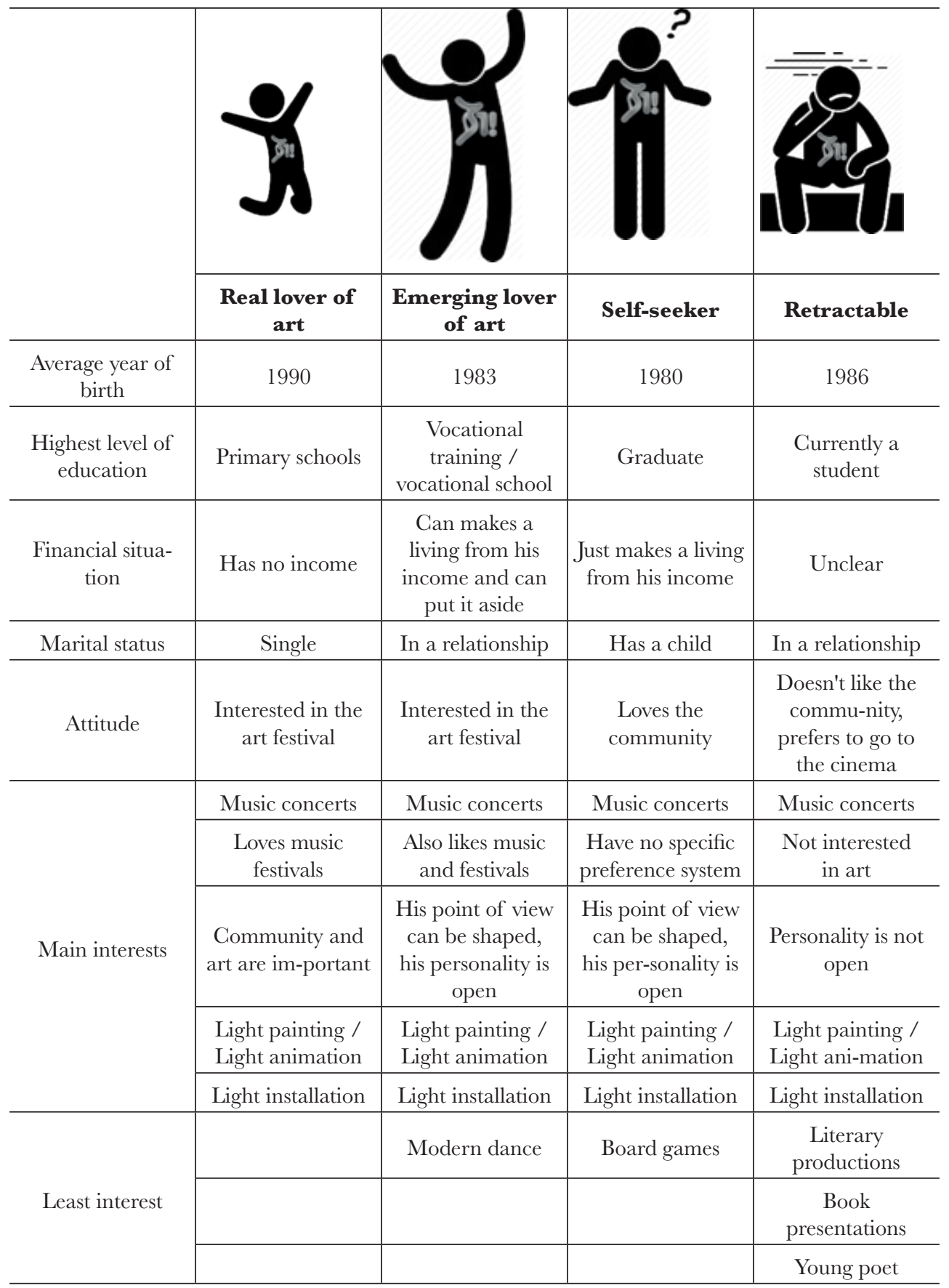

Source: IMB SPSS output table (created by own analysis) 
Light art lovers are typically graduates $(30.9 \%)$, but many younger visitors of the happening who have completed elementary school $(20.6 \%)$ are also included. Among Super art lovers, there are even more graduates $(46.9 \%)$ and people who finished vocational training / vocational school $(21.9 \%)$. University graduates are represented in the Open-minded community at the same rate $(25 \%)$ as secondary school graduates $(25 \%)$. Most of Style finders finished vocational education $(29.5 \%)$ or are secondary school graduates $(25 \%)$. The distribution of the most typical marital status is as follows:

- Light art lovers: 36.4\% single; 27.3\% without a child in a relationship; $21.2 \%$ have children.

- Super art lovers: 28.1\% raising children, 25\% living in a relationship, $18.8 \%$ single.

- Open-minded: 44.4\% single, 22.2\% married or in a relationship, $16.7 \%$ in a relationship.

- Style finders: $29.5 \%$ in a relationship, $27.3 \%$ single, and $25 \%$ raising a child.

As for the average year of birth of the cluster groups determined by the data of the local questionnaire, the average year in which both Light art lovers and Style finders were born was 1989 (for the former the standard deviation was 12.61, while for the latter it was 13.56); for $\mathrm{Su}$ per art lover it was $1979(\sigma=16,47)$, and 1975 for the Open-minded $(\sigma=16.85)$.

Table 6 explains the assessment of the programmes. The data presented are relevant to show the scores of those who actually participated in specific programs. 106 of the local questionnaire respondents $(\mathrm{n}=235)$ attended the dance performance. This programme captured the Open-minded the most, while the average value of the other clusters is below 4 (minimum 1 and maximum 6), so we cannot talk about clear satisfaction in their case. The light painting / light installation (107 participants) became the favourite of Super art lovers with an average value of 5.24, and they also have the lowest standard deviation; however, the examined programme performed above 3 in all cases, so overall its assessment tends to be more positive. Also, the second cluster is most passionate about sand animation and UV felting (5.00 with an average of 1.48 standard deviation), but in both cases it performed below an average of 3 with 107 also present. Surprisingly, perhaps only about half of the respondents (110 people) were present at the concerts, as this met the needs of almost everyone, but it should be noted that the survey took place during the day, so it is possible that not all respondents had the opportunity to listen to music. 103 of them participated in literary / poetic programmes, from which of course Super art lovers gained the highest satisfaction (average 5.12), but this figure was significantly lower among Style finders, with an average of 1.83. (although the standard deviation is above 2). According to the 107 participants in the community programmes surveyed, its positive mood was also a primary option for the Open-minded (average 4.50). The relatively low number of spectators in the photo exhibition (106 people) is also surprising, as it is almost impossible to enter 31 ! without seeing exhibited images. It is also interesting that in this case Super art lovers do not belong to the forefront, but it rather caught the attention of Light art lovers (average: 4.28) and the Open-minded (average: 4.66). Architectural installations attracted clusters with an overall average of 3.41 and 107 participants. The fine arts workshop was attended by 108 people, but shows numbers below 4 for each cluster, so it is definitely worth emphasizing the development of the programme in the coming years.

Overall, local respondents are more interested in the following programmes offered by 31 !:

- dance performances (on average $\sum=$ 4,60 , at the happening $\left.\sum=3,94\right)$,

- photo exhibition (on average $\sum=4,59$, at the happening $\sum=4,00$,

- music concerts (on average $\sum=5,06$, at the happening $\left.\sum=4,58\right)$,

- light painting (on average $\sum=3,94$, at the happening $\sum=4,81$,

- literary productions (on average $\sum=$ 3,48 , at the happening $\sum=4,09$ ). 
It is a positive result that visitors had a good time at 31!. The most enthusiastic ones were Light art lovers, who gave an average score of 5.63 to the question ("Overall, how much do you enjoy yourself at 31 !?") They were followed by Super art lovers with a mean of 5.61 $(\sigma=0.77)$, followed by the Open-minded ( 5.27 mean, 0.86 standard deviation). Style finders were a bit more uncertain about this question as well, but they also had a positive result with an average of 4.75 (standard deviation 1.29).

Table 6: Assessment of the programmes offered by 31! by clusters based on participation ( $n=215)$

\begin{tabular}{|c|c|c|c|c|c|c|c|}
\hline $\begin{array}{l}\text { Prog- } \\
\text { ram }\end{array}$ & Cluster & Mean & St. dev. & $\begin{array}{l}\text { Prog- } \\
\text { ram }\end{array}$ & Cluster & Mean & St. dev. \\
\hline \multirow{5}{*}{ 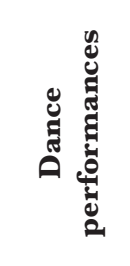 } & Light art lover & 3,47 & 2,555 & \multirow{5}{*}{ 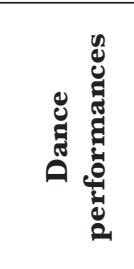 } & Light art lover & 3,53 & 2,458 \\
\hline & Super art lover & 3,37 & 2,565 & & Super art lover & 4,16 & 2,455 \\
\hline & Open-minded & 4,17 & 2,230 & & Open-minded & 4,50 & 2,162 \\
\hline & Style finder & 2,95 & 2,368 & & Style finder & 2,85 & 2,231 \\
\hline & $\sum$ clusters & 3,56 & 2,438 & & $\sum$ clusters & 3,79 & 2,379 \\
\hline \multirow{5}{*}{ 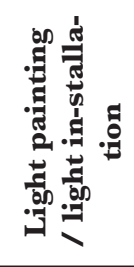 } & Light art lover & 3,93 & 2,454 & \multirow{5}{*}{ 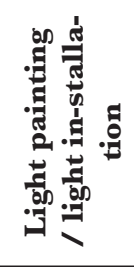 } & Light art lover & 4,28 & 2,271 \\
\hline & Super art lover & 5,24 & 1,480 & & Super art lover & 3,83 & 2,526 \\
\hline & Open-minded & 3,80 & 2,578 & & Open-minded & 4,66 & 1,738 \\
\hline & Style finder & 3,10 & 2,553 & & Style finder & 2,65 & 2,412 \\
\hline & $\sum$ clusters & 3,94 & 2,437 & & $\sum$ clusters & 4,00 & 2,293 \\
\hline \multirow{5}{*}{ 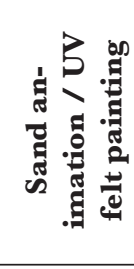 } & Light art lover & 2,90 & 2,604 & \multirow{5}{*}{ 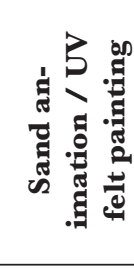 } & Light art lover & 3,05 & 2,724 \\
\hline & Super art lover & 5,00 & 1,572 & & Super art lover & 4,72 & 2,218 \\
\hline & Open-minded & 3,26 & 2,543 & & Open-minded & 3,73 & 2,377 \\
\hline & \begin{tabular}{|l|} 
Style finder \\
\end{tabular} & 2,16 & 2,167 & & Style finder & 2,45 & 2,328 \\
\hline & $\sum$ clusters & 3,22 & 2,496 & & $\sum$ clusters & 3,41 & 2,551 \\
\hline \multirow{5}{*}{ نَّ } & Light art lover & 4,69 & 2,0539 & \multirow{5}{*}{ 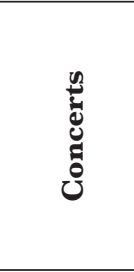 } & Light art lover & 3,38 & 2,569 \\
\hline & Super art lover & 5,00 & 1,1547 & & Super art lover & 3,50 & 2,640 \\
\hline & Open-minded & 4,61 & 1,9609 & & Open-minded & 3,67 & 2,604 \\
\hline & Style finder & 3,93 & 2,0575 & & Style finder & 2,30 & 2,203 \\
\hline & $\sum$ clusters & 4,58 & 1,9084 & & $\sum$ clusters & 3,28 & 2,539 \\
\hline \multirow{5}{*}{ 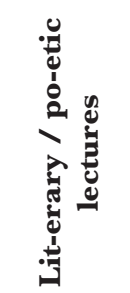 } & Light art lover & 3,34 & 2,464 & & & & \\
\hline & Super art lover & 5,12 & 1,536 & & & & \\
\hline & Open-minded & 3,70 & 2,437 & & & & \\
\hline & Style finder & 1,83 & 2,036 & & & & \\
\hline & $\sum$ clusters & 3,48 & 2,429 & & & & \\
\hline
\end{tabular}

Source: IMB SPSS output table (created by own analysis) 
Table 7: General assessment of programmes based on clusters $(n=215)$

\begin{tabular}{|c|c|c|c|c|c|c|c|}
\hline $\begin{array}{l}\text { Prog- } \\
\text { ram }\end{array}$ & Cluster & Mean & St. dev. & $\begin{array}{l}\text { Prog- } \\
\text { ram }\end{array}$ & Cluster & Mean & St. dev. \\
\hline \multirow{5}{*}{ 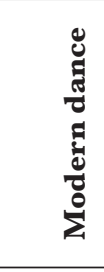 } & Light art lover & 5,03 & 1,349 & \multirow{5}{*}{ 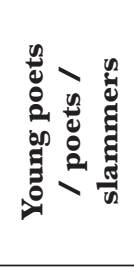 } & Light art lover & 4,47 & 1,588 \\
\hline & Super art lover & 4,23 & 1,612 & & Super art lover & 5,03 & 1,224 \\
\hline & Open-minded & 4,86 & 1,079 & & Open-minded & 4,63 & 1,238 \\
\hline & Style finder & 3,74 & 1,761 & & Style finder & 3,12 & 1,942 \\
\hline & $\sum$ clusters & 4,60 & 1,478 & & $\sum$ clusters & 4,33 & 1,632 \\
\hline \multirow{5}{*}{ 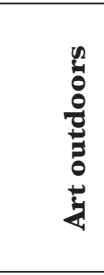 } & Light art lover & 4,54 & 1,440 & \multirow{5}{*}{ 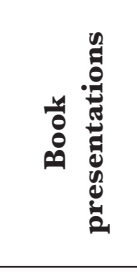 } & Light art lover & 3,75 & 1,652 \\
\hline & Super art lover & 5,03 & 1,295 & & Super art lover & 5,45 &, 624 \\
\hline & Open-minded & 4,78 & 1,078 & & Open-minded & 4,59 & 1,305 \\
\hline & Style finder & 3,49 & 1,696 & & Style finder & 2,98 & 1,752 \\
\hline & $\sum$ clusters & 4,48 & 1,455 & & $\sum$ clusters & 4,12 & 1,652 \\
\hline \multirow{5}{*}{$\begin{array}{l}0 \\
0 \\
0 \\
0 \\
0 \\
0 \\
0 \\
0 \\
0 \\
0 \\
0 \\
0\end{array}$} & Light art lover & 4,72 & 1,337 & \multirow{5}{*}{ 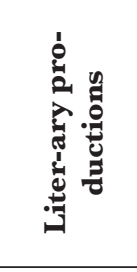 } & Light art lover & 3,94 & 1,650 \\
\hline & Super art lover & 5,10 & 1,165 & & Super art lover & 5,16 & 1,098 \\
\hline & Open-minded & 4,85 & 1,159 & & Open-minded & 4,52 & 1,340 \\
\hline & Style finder & 3,58 & 1,607 & & Style finder & 2,81 & 1,742 \\
\hline & $\sum$ clusters & 4,59 & 1,407 & & $\sum$ clusters & 4,09 & 1,669 \\
\hline \multirow{5}{*}{ 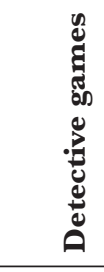 } & Light art lover & 4,13 & 1,714 & \multirow{5}{*}{ 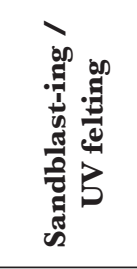 } & Light art lover & 4,38 & 1,526 \\
\hline & Super art lover & 4,48 & 1,703 & & Super art lover & 4,94 & 1,315 \\
\hline & Open-minded & 4,24 & 1,439 & & Open-minded & 4,68 & 1,339 \\
\hline & Style finder & 2,88 & 1,841 & & Style finder & 3,48 & 1,890 \\
\hline & $\sum$ clusters & 3,96 & 1,734 & & $\sum$ clusters & 4,38 & 1,585 \\
\hline \multirow{5}{*}{ 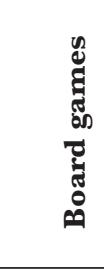 } & Light art lover & 3,96 & 1,731 & \multirow{5}{*}{ 总 } & Light art lover & 4,69 & 1,569 \\
\hline & Super art lover & 4,87 & 1,477 & & Super art lover & 5,28 & 1,170 \\
\hline & Open-minded & 4,30 & 1,448 & & Open-minded & 4,92 & 1,230 \\
\hline & Style finder & 3,07 & 1,827 & & Style finder & 4,09 & 1,688 \\
\hline & $\sum$ clusters & 4,03 & 1,711 & & $\sum$ clusters & 4,73 & 1,472 \\
\hline \multirow{5}{*}{ 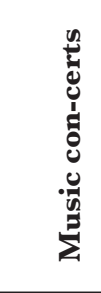 } & Light art lover & 5,34 & 1,109 & \multirow{5}{*}{ 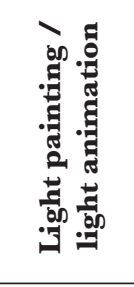 } & Light art lover & 4,87 & 1,495 \\
\hline & Super art lover & 5,34 & 1,096 & & Super art lover & 5,32 & 1,137 \\
\hline & Open-minded & 5,17 & ,862 & & Open-minded & 5,04 & 1,250 \\
\hline & Style finder & 4,25 & 1,767 & & Style finder & 3,95 & 1,834 \\
\hline & $\sum$ clusters & 5,06 & 1,268 & & $\sum$ clusters & 4,81 & 1,505 \\
\hline
\end{tabular}

Source: IMB SPSS output table (created by own analysis) 
Table 8: Cluster analysis summary table based on local questionnaires

\begin{tabular}{|c|c|c|c|c|}
\hline & & & & \\
\hline & Light art lover & Super art lover & Open-minded & Style finder \\
\hline $\begin{array}{l}\text { Average year of } \\
\text { birth }\end{array}$ & 1989 & 1979 & 1975 & 1989 \\
\hline $\begin{array}{l}\text { Highest level of } \\
\text { education }\end{array}$ & Graduate & Graduate & $\begin{array}{l}\text { High School / } \\
\text { Graduate }\end{array}$ & $\begin{array}{c}\text { Vocational } \\
\text { training / } \\
\text { vocational school }\end{array}$ \\
\hline $\begin{array}{c}\text { Financial situa- } \\
\text { tion }\end{array}$ & Single & Has a child & Single & In a relationship \\
\hline Marital status & $\begin{array}{l}\text { Doesn't like book } \\
\text { shows, but interes- } \\
\text { ted in art festivals }\end{array}$ & $\begin{array}{l}\text { They love the } \\
\text { arts, book shows, } \\
\text { serious music, } \\
\text { theatre }\end{array}$ & $\begin{array}{l}\text { Extremely open } \\
\text { all in the direction } \\
\text { of easy entertain- } \\
\text { ment and the arts } \\
\text { as well }\end{array}$ & $\begin{array}{l}\text { They are not } \\
\text { characterized by } \\
\text { openness, they } \\
\text { have no definite } \\
\text { interest }\end{array}$ \\
\hline \multirow{5}{*}{$\begin{array}{c}\text { Attitude } \\
\text { Main interests }\end{array}$} & Music concert & Book presentation & Music concerts & Music concerts \\
\hline & Modern dance & Music concerts & $\begin{array}{l}\text { Light painting / } \\
\text { Light animation }\end{array}$ & Light installation \\
\hline & $\begin{array}{l}\text { Light painting / } \\
\text { Light animation }\end{array}$ & $\begin{array}{l}\text { Light painting / } \\
\text { Light animation }\end{array}$ & Light installation & \\
\hline & Light installation & $\begin{array}{c}\text { Literary } \\
\text { productions }\end{array}$ & & \\
\hline & & Light installation & & \\
\hline \multirow{3}{*}{ Least interest } & Book presentation & & & $\begin{array}{c}\text { Book } \\
\text { presentations }\end{array}$ \\
\hline & $\begin{array}{c}\text { Literary } \\
\text { production }\end{array}$ & & & $\begin{array}{l}\text { Literary produc- } \\
\text { tions }\end{array}$ \\
\hline & & & & $\begin{array}{l}\text { Community pro- } \\
\text { grams }\end{array}$ \\
\hline
\end{tabular}

Source: IMB SPSS output table (created by own analysis)

\section{SUMMARY}

The constructive role of festivals and happenings in community development cannot be neglected in the development of cities and raising awareness about them. Nowadays, it is important to pair up culture with entertainment; the goal is to be unique, to provide an experience, and to be able to adapt to today's fast-paced lifestyle. Creating cultural value is a social interest, perhaps never before has it been so necessary to influence the cultural habits of young people to become culture lovers and 


\section{Tudományos mühely}

consumers in adulthood.

Undoubtedly, the 31 ! happening in Hungary plays a major role in connecting and mediating different art genres and elements, helping to preserve local culture and traditions. 31!, which takes place in 3 venues, is a great opportunity, especially for young people, to get closer to the fun, and an abundance of it. However, it is also an excellent opportunity for Győr to strengthen its regional role, to occupy a more prominent place in the hierarchy of settlements, and to develop the city using well-established methods at the international level. The consciously applied programme offer, the well-known and identifiable target audience, and the attention of stakeholders through 31 ! helps urban development, sets an example of successful differentiation, and also joins international trends.

\section{LITERATURE}

Borg, J. v. d. (1994): Demand for city tourism in Europe: tour operators' catalogue. Tourism Management, 15(1), 66-69.

Enyedi György (2005): A városok kulturális gazdasága In: Enyedi, Gy. - Keresztély ,K. (szerk.): A magyar városok kulturális gazdasága pp. 13-22., MTA Társadalomkutató Központ, Budapest

European Communities (2009): European Capitals of Culture: The road to success. From 1985 to 2010. Luxembourg, Luxemburg https://ec.europa.eu/programmes/creative-europe/sites/creative-europe/files/ library/capitals-culture-25-years_en.pdf Letöltés: 2020. 09.25.

Fekete Dávid (2018): Latest Results of the Győr Cooperation Model. Polgári Szemle, 14, pp. 195-209.

Fekete Dávid - Rechnitzer János (2019): Együtt nagyok. Város és vállalat 25 éve. Dialóg Campus Kiadó, Budapest

Haywood, K. M. - Muller, T. E. (1988): The urban tourist experience: evaluation satisfaction. Hospitality Education and Research fournal, 453-459.

Internet-1: https://brnodaily.com/2020/05/20/ events-in-brno/luzanky-parks-ponavafest-to-returnas-a-series-of-smaller-concerts-from-may-to-august/ downloaded: 2020.09.21

Internet-2: https://www.visitmaribor.si/en/whatto-do/events-and-shows/calendar-of-events/5951-lent-festival-international-multicultural-fes- tival downloaded: 2020.09.21.

Internet-3: https://rudaslaska.naszemiasto.pl/tag/holi-festival-ruda-slaska downloaded: 2020.09.21.

Internet-4: https://www.arcanum.hu/hu/online-kiadvanyok/MagyarNeprajz-magyar-neprajz-2/ iv-eletmod-41AA/telepules-41D4/telepules-es-telepuleskutatas-41D5/a-telepules-fogalma-a-telepulesek-fajtai-41D6/ downloaded: 2020.09.21.

Jászberényi Melinda - Ásványi Katalin (2016): A Fesztiválturizmus és annak társadalmi-kulturális hatása a helyben lakó közösségre, In: Turizmus és Innováció": VIII. Nemzetközi Turizmus Konferencia 2016: Tanulmányok Isbn:9786155391811 pp. 331-338.

Jászberényi Melinda - Zátori Anita - Ásványi Katalin (szerk.) (2017): Fesztiválturizmus, Budapest, Akadémiai Kiadó

Kundi Viktória (2012): Fesztiválok gazdasági hatásmérésére alkalmazott nemzetközi és hazai modellek bemutatása, Tér és Társadalom, 26. évf., 4. szám, p. $93-108$

Lehota József (2001): Marketingkutatás az agrárgazdaságban, Mezőgazda Kiadó, Busapest, pp. 148.

Pachaly, C. (2008): Kulturhauptstadt Europas Ruhr $2010-$ Ein Festival als Instrument der Stadtentwicklung, Institut für Stadt- und Regionalplanung, Berlin 2008, pp. 16-23

Smith, M. (2009): Fesztiválok és turizmus: lehetőségek és konfliktusok, In: Turizmus Bulletin, XIII. évf. 3. szám, Budapest, pp. 23-27.

Szabó János Zoltán (2011): Kulturális fesztiválok mint a mưvelödés új formái, Doktori Értekezés, Debrecen, downloaded: 2020. 09.25. https://dea.lib.unideb.hu/dea/bitstream/handle/2437/129798/ Szabo_Janos_Zoltan_Ertekezest.pdf;jsessionid $=450290 \mathrm{C} 4 \mathrm{C} 5 \mathrm{~B} 920883065 \mathrm{BDE} 3 \mathrm{~A} 8 \mathrm{DA}$ $5 \mathrm{FC} 2$ ? sequence $=5$

Szabó János Zoltán (2014): A fesztiváljelenség, Kultindex Nonprofit Kft., Budapest

Szirmai Viktória (1996): Közép-európai új városok az átmenetben. Szociológiai szemle. 3-4., 181-205.

Tóthné Kardos Krisztina (2016): A győri turizmus elemzése a lakosság véleményének figyelembevételével, Polgári Szemle Gazdasági és Társadalmi Folyóirat 12:4-6 pp. 352-368. 